\title{
Three decades of modelling Minsky: what we have learned and the way forward
}

\author{
Maria Nikolaidi
}

\begin{abstract}
This paper intends to contribute to the contemporary discussions about Minsky's economics by reviewing how the key ideas of Minsky have been formalised in the heterodox literature over the last three decades or so. First, a distinction is made between the different models based on (a) the source of financial instability they focus on, (b) the type of heterodox macroeconomic framework into which Minskyan ideas are incorporated and (c) the purpose and the nature of the dynamic analysis. Second, the key lessons learned from modelling Minsky are outlined. Finally, the paper calls for more empirically-driven models, points out the usefulness of agent-based approaches and highlights the need for the development of Minsky models on open economy, shadow banking and environmental issues.
\end{abstract}

Keywords: Minsky, financial instability, post-Keynesian economics

JEL codes: E12, E32, E44

July 2017

Address for correspondence: Department of International Business and Economics, University of Greenwich, London, UK; email: M.Nikolaidi@greenwich.ac.uk

Acknowledgements. I am grateful to Yannis Dafermos and Engelbert Stockhammer for useful comments and discussions. An earlier version of the paper was presented at the 20th Conference of the Research Network Macroeconomics and Macroeconomic Policies (FMM), Berlin, October 2016. I would like to thank the participants for helpful feedback. Any errors are mine. 


\section{Three decades of modelling Minsky: what we have learned and the way forward}

\section{Introduction}

Since the global financial crisis, there has been a growing consensus among mainstream and non-mainstream economists that Minsky's financial instability hypothesis (FIH) is a useful platform for analysing the causes and the implications of financial crises. This is not by coincidence. Minsky's theory (Minsky 1975; 1982; 1986 [2008]) provides a very rich framework for understanding the interactions between debt structures, asset prices, expectations and institutional transformations that moves beyond the standard macroeconomic analysis in which the financial system is merely a source of 'frictions' in an otherwise well-behaved economy. His FIH shows how periods of stability can transform financial behaviour and institutions in a way that is conducive to higher financial fragility, sowing the seeds for a financial collapse.

A question that often arises is whether it is possible and necessary to model Minsky's ideas. The short answer is 'no'. Minsky's analysis includes many rich institutional and dynamic aspects that cannot be easily incorporated in a macroeconomic model. And there is a large Minskyan literature that has provided insightful analyses of key macroeconomic and financial issues without relying at all on modelling techniques (see e.g. Kregel 2008; Wray 2009 and the references therein). However, modelling Minskyan ideas can be useful. The principal reason is that formal models permit a more detailed understanding of the implications of Minsky's theoretical assumptions and it can allow us to identify the exact conditions under which cycles and instability can (or cannot) arise.

The modelling of Minskyan ideas started in the mid 1980s when Taylor/O'Connell (1985) published their well-known article about the modelling of a Minsky crisis. Since then, a large number of Minsky macroeconomic models have been developed which incorporate Minskyan insights into heterodox analytical frameworks. Although all these models share their inspiration from Minsky, they tend to have substantial differences in the financial channels they focus on, the analytical settings that they use and the type of dynamic analysis that they conduct. For example, some models focus on corporate debt and its interaction with investment, while others pay attention to household debt and its interaction with asset prices. Some models analyse Minsky using a Kaleckian framework while others rely on Kaldorian or Goodwinian setups. Also, one can find models that have as an aim to show how cycles emerge but also models that confine their attention to the conditions under which stability or instability arise, without having an explicit analysis of cycles.

The aim of this paper is to analyse and classify the different types of heterodox Minsky models (section 2), outline the lessons that have been learned (section 3) and provide some avenues for future research (section 4). We have deliberately chosen to focus on the heterodox literature on Minsky modelling since the models of this literature are arguably closer to Minsky's analytical framework who was not in favour of general equilibrium analysis. However, there are various recent attempts to incorporate Minskyan ideas into mainstream analytical settings; interested readers can be referred to Eggertsson/Krugman (2012), Farmer (2013) and Bhattacharya et al. (2015). 


\section{Classifying Minsky models}

There are at least three key areas in which the Minsky models differ: (a) the source of financial instability; (b) the type of heterodox macroeconomic framework into which Minskyan ideas are incorporated; (c) the purpose and the nature of the dynamic analysis. ${ }^{1}$

Regarding the first area, most Minsky models concentrate on the role of corporate debt, following Minsky's emphasis on the financial contracts between firms and banks. Some of these models simply concentrate on the demand for credit by firms and examine how firms' indebtedness can be a source of financial fragility. Other models have a more detailed look at the decisions of banks about the provision of business loans, emphasising the impact of banks' behaviour on fragility. There are also models that analyse corporate debt in combination with equity prices, paying particular attention to the role of the stock market in the emergence of financial fragility. Despite the fact that Minsky paid little attention to household debt, there are also Minsky models that analyse how the financial structure of households can be a source of fragility. Some of these models focus on consumer debt, while other models examine the interaction between mortgages and the real estate prices.

Turning to the second area, there is no consensus on whether Minsky should be analysed within a Kaleckian, Kaldorian, Goodwinian or another heterodox macroeconomic framework. Many scholars have simply incorporated debt into an otherwise standard Kaleckian model, others have relied on a Kaldorian view about the behaviour of the goods market and some others have used the traditional Goodwin model that shows the interactions between wages and capital accumulation and have explored how debt can affect this interaction.

Finally, there is significant divergence in the way that the dynamic analysis is conducted in the Minsky models. Many models are simply used to analyse the conditions under which stability or instability can arise while other models pay much more attention to the way that cycles can be generated. Also, there are models that are solved only analytically but also models whose dynamic properties are explored only via simulations.

The classification of Minsky models shown in Figure 1 relies on areas (a) and (b). We first make a broad distinction between corporate debt and household debt models and then we present sub-categories of Minsky models based on the type of heterodox framework that is used and the specific source of instability on which each group of models concentrates. ${ }^{2} \mathrm{~A}$ different way of classifying the Minsky models, without changing the sub-categories, would be to make a broad distinction between (i) the models that focus on the dynamics of debt and interest rate without considering the role of asset prices and (ii) those models in which equity or real estate prices are the key drivers of the model dynamics. Such a classification is presented in Nikolaidi/Stockhammer (2017). ${ }^{3}$

\footnotetext{
${ }^{1}$ For a more detailed analysis of the differences between the Minsky models see Nikolaidi/Stockhammer (2017).

${ }^{2}$ By making a distinction between corporate debt and household debt models, our categorisation excludes by definition the Minsky models that examine corporate and household debt in conjunction (e.g. Setterfield 2004; Isaac/Kim 2013) and the Godley-Minsky model of Dafermos (2017) that focuses on the overall debt of the private sector.

${ }^{3}$ Nikolaidi/Stockhammer (2017) include in their classification an additional sub-category of Minsky models in which the expenditures of the private sector and the dynamics of debt are affected by endogenous target debt ratios.
} 


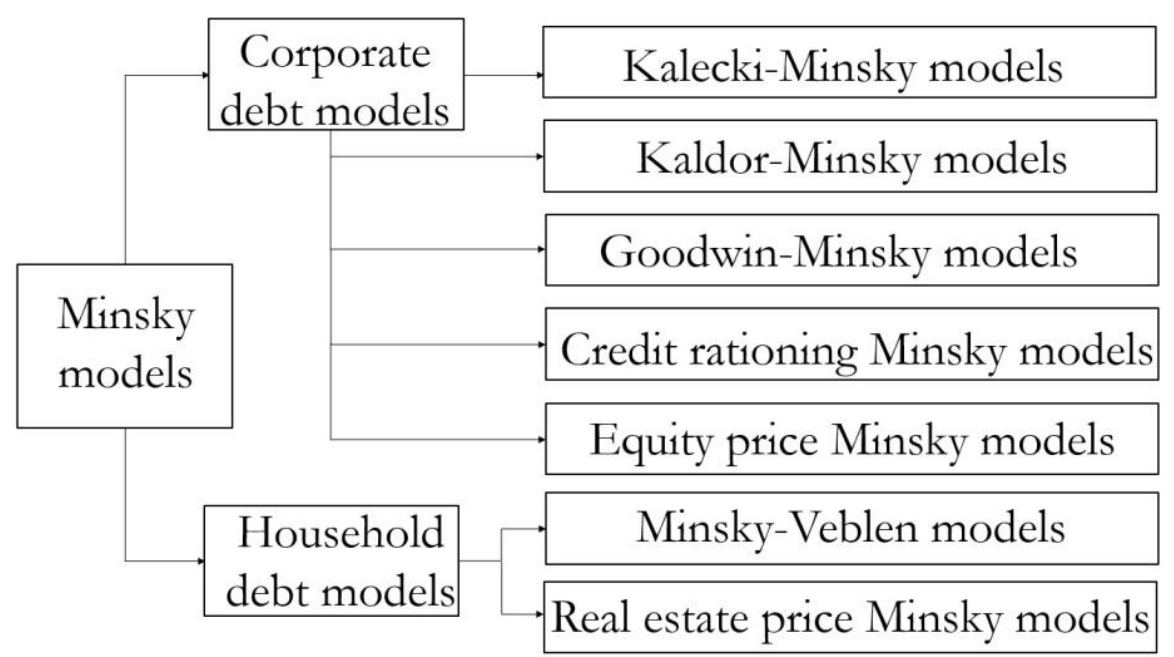

Figure 1 A classification of Minsky models

Source: own depiction.

\subsection{Corprorate debt Minsky models}

The corporate debt Minsky models postulate a closed economy that consists of households, firms and banks. Households consume all or part of their income and do not take out loans. The firm sector is the only sector that accumulates debt and banks provide corporate loans either on demand or by applying some type of credit rationing.

\subsubsection{Kalecki-Minsky models}

In the Kalecki-Minsky models (e.g. Dutt 1995; Lavoie 1995; Lima/Meirelles 2007; Charles 2008; Fazzari et al. 2008; Nishi 2012; Sasaki/Fujita 2012) firms' investment rate is typically captured by a Kaleckian investment function. Investment is affected by various factors, such as gross profits, capacity utilisation and interest payments. Debt is the residual in the budget constraint of firms. This means that firms use bank loans to finance the investment expenditures that are not covered by retained profits. Loans are provided by banks on demand (i.e. there is no credit rationing) and there is no equity market. Typically, there are two types of households: workers and rentiers. Workers usually consume all their income (wage share is exogenous) while rentiers, whose income comes from the distributed profits of firms and interest on deposits, save part of it. The goods market is assumed to be stable (i.e. the Keynesian stability condition holds) and capacity utilisation adjusts to ensure stability. Financial fragility is typically measured by firms' debt-to-capital ratio (i.e. the leverage ratio). ${ }^{4}$

In most Kalecki-Minsky models the interaction between the real economy and the financial market can be captured by a dynamic system which has the investment rate and the debt-tocapital ratio as state variables. Despite the fact that cycles are important in Minsky's FIH, most Kalecki-Minsky models do not focus on the conditions under which cycles emerge. ${ }^{5}$ They

\footnotetext{
${ }^{4}$ Some Kalecki-Minsky models measure financial fragility by relying on Minsky's categorisation of hedge, speculative and Ponzi finance regimes (see Lima/Meirelles 2007; Nishi 2012; Sasaki/Fujita 2012). There is also a large literature on Minsky's finance regimes which is not confined to the firm sector. For example, Ferrari-Filho et al. (2010) and Argitis/Nikolaidi (2014) have applied this classification to the public sector and Vercelli (2011) has suggested some general financial fragility indices that take into account both solvency and liquidity problems and can be applied to all economic units.

${ }^{5}$ Fazzari et al. (2008) present cycles in their simulations, but they do not provide analytical solutions.
} 
simply analyse how stability and instability arises and most of them pay particular attention to the conditions under which the firm sector converges towards a hedge, speculative or a Ponzi regime (see, for example, Lima/Meirelles 2007; Charles 2008; Nishi 2012; Sasaki/Fujita 2012).

However, the Kalecki-Minsky models can generate cycles. These cycles behave as follows. Suppose that the debt-to-capital ratio and the investment rate are initially low. The low debtto-capital ratio means that the interest payments of firms are low and this leads them to increase their investment. Due to its procyclicality, the debt-to-capital ratio increases, meaning that we are in a boom phase in which there is a combination of high investment and high financial fragility. However, once the debt-to-capital ratio has become sufficiently high, investment rate starts decreasing because interest payments are high (this is the bust period). The decline in investment eventually reduces the debt-to-capital ratio, allowing the start of a new cycle.

What about the role of the interest rate in the Kalecki-Minsky models? There is no consensus on that. Some models (e.g. Nishi 2012; Sasaki/Fujita 2012) assume that the interest rate is exogenous while other models make it endogenous, assuming that it is a function of the leverage ratio (see Charles 2008) or economic activity (see Lima/Meirelles 2007; Fazzari et al. 2008). It can be argued that an endogenous interest rate generally accelerates the end of the boom and the bust periods since it increases (decreases) more quickly the interest payments in the upward (downward) phase.

Two issues are worth mentioning. First, one of the key parameter that affects the stability/instability of the dynamic system of Kalecki-Minsky models is the sensitivity of investment to the profit rate of firms. When this sensitivity is high, instability is more likely because firms have a more aggressive investment behaviour that tends to increase their leverage ratios. Second, there are many studies that call into question the assumption of a procyclical leverage ratio (see Lavoie 1995; Lavoie/Seccareccia 2001; Hein 2007). These studies rely on the idea of the 'paradox of debt': even though firms might want to increase (decrease) their investment rate and debt-to-capital ratio, they might end up with a lower (higher) debt-to-capital ratio since higher (lower) debt-financed investment might lead to higher (lower) profits through higher (lower) macroeconomic activity. Charles (2016) has shown that the paradox of debt is more likely when the retention rate of firms is high and/or the sensitivity of investment to the profit rate is low. ${ }^{6}$

\subsubsection{Kaldor-Minsky models}

Most Kaldor-Minsky models have a similar structure with the Kalecki-Minsky models (e.g. Semmler 1987; Jarsulic 1989; Asada 2001). However, there are Kaldor-Minsky models that depart form this typical structure. For example, Foley (1987) constructs a model with Marxian characteristics while Skott (1994) develops a more abstract model where financial fragility is captured by the ratio of interest payments to normal profits and tranquillity is proxied by the ratio of interest payments to actual profits.

The main difference between the Kaldor-Minsky models and the Kalecki-Minsky models is that the former assume an unstable goods market since the responsiveness of the investment rate to capacity utilisation is higher than the responsiveness of the saving rate (i.e. the Keynesian stability does not hold). This implies that the goods market in these models is inherently unstable.

\footnotetext{
${ }^{6}$ For a critique to the 'paradox of debt' approach, see Ryoo (2013c).
} 
Moreover, the dynamic analysis of most Kaldor-Minsky models focuses on the conditions under which cycles can emerge. For example, Foley (1987), Semmler (1987) and Asada (2001) analyse how cycles can arise when key parameters (such as the elasticity of borrowing with respect to the profit rate-interest rate differential or the responsiveness of profits to aggregate demand) take specific values, while Jarsulic (1989) and Skott (1994) use non-linear investment functions and show how cycles emerge in models that are locally unstable but globally stable. The rationale of the cycles is close to the one described above for the Kalecki-Minsky models. The key difference is that during the boom firms tend to increase much more their investment, accelerating the increase in financial fragility (given that their leverage ratio is procyclical). The opposite happens during the bust periods.

\subsubsection{Goodwin-Minsky models}

In the Goodwin-Minsky models (Keen 1995, 2013; Grasselli/Costa Lima 2012) the structure of the economy is very close to the one used in the Kalecki-Minsky and Kaldor-Minsky models. However, they differ in two key aspects. First, the wage share is endogenous: wages increase when the unemployment rate declines because of the rise in the bargaining power of workers. Second, output is supply-determined (economic growth is determined by the growth rate of capital stock). ${ }^{7}$ There is no consensus on the endogeneity/exogeneity of the interest rate. Keen (1995) assumes an endogenous interest rate while Grasselli/Costa Lima (2012) and Keen (2013) take it as an exogenous variable.

The interest payments of firms play an important role in the dynamics of the GoodwinMinsky models. In the traditional Goodwin model (which does not include financial aspects), an increase in investment makes employment rate higher, causing a rise in the wage share. This increase in the wage share reduces investment, giving rise to a bust. When debt is incorporated into the Goodwin model, this profit squeeze during the boom is reinforced by the rise in the interest payments of firms. These payments increase both because the leverage ratio is pro-cyclical and, if the interest rate is endogenous, because the lending interest rate is assumed to increase as the indebtedness of firms increases.

What are the key factors that determine whether the dynamics of the Goodwin-Minsky models are unstable? In his simulations, Keen (1995) illustrates that instability is more likely when the base interest rate is high and the responsiveness of the lending interest rate to the leverage ratio is large. Grasselli/Costa Lima (2012) show that instability can more easily arise when the parameters in the investment function imply that firms invest much more than their net profits in the boom period.

\subsubsection{Credit rationing Minsky models}

In the Kalecki-Minsky, Kaldor-Minsky and Goodwin-Minsky models there is no explicit mechanism of credit rationing and banks' financial position does not affect the availability of credit. This is not in line with Minsky who argued:

\footnotetext{
7 Keen's (1995) model can be modified to include the role of demand (see Sordi/Vercelli 2014). Also, it is possible to have pseudo-Goodwin cycles in a Minsky model when output is demand-determined and demand is wage-led (see Stockhammer/Michell 2017).
} 
'The higher leverage ratio of banks was part of the process that moved the economy toward financial fragility because it facilitated an increase in short-term borrowing (and in leverage) by bank customers: the leverage ratio of banks and the import of speculative and Ponzi financing in the economy are two sides of a coin' (Minsky 1986 [2008]: 265).

The credit rationing Minsky models link explicitly the financial position of banks with the credit provision process. Ryoo (2013b) assumes that banks' credit supply depends on bank profitability. During the boom phase, the profitability of banks improves and this makes them more willing to expand credit. Instability is more likely when credit supply responds strongly to bank profitability.

Nikolaidi (2014) uses a model that distinguishes between the desired and the effective investment of firms. Effective investment is lower than desired investment due to credit rationing. It is postulated that credit rationing depends on the leverage ratio of banks. During the boom phase banks increase their target leverage ratio due to the euphoric expectations. This induces them to provide more loans, boosting effective investment. Instability is more likely when the responsiveness of the target leverage ratio to the economic cycle is high.

\subsubsection{Equity price Minsky models}

All the previous models assume away the role of equity prices. This is not the case in the equity price Minsky models in which firms' investment is financed with a combination of debt and equity. This implies that the household portfolio choice plays a key role in the model dynamics.

The most recent integrated equity price Minsky model has been developed by Ryoo (2010, 2013a), which shares many similarities with the models of Taylor/O'Connell (1985), Franke/Semmler (1989), Delli Gatti/Gallegati (1990) and Delli Gatti et al. (1994) that were some of the first models that analysed Minskyan dynamics focusing on the role of asset prices. In Ryoo's model equity prices affect positively economic activity, equity is the residual source of finance and the dynamics of debt are determined by the profits-to-interest payments ratio, which serves as a margin of safety for both firms and banks (the higher the ratio the higher the willingness of firms to take out loans and the desire of banks to expand credit). Households invest their wealth either in equities or deposits.

The model has both a Kaleckian version, in which capacity utilisation is endogenously determined, and a Kaldorian version in which capacity utilisation is exogenous. We will focus here on the Kaldorian version which includes both short cycles and long waves. The short cycles rely on Skott's (1989) model in which cycles are produced as a result of the interaction between the goods market and the labour market. The long waves refer to financial processes and are produced through the interaction between the equity-to-deposits ratio, the expected rate of return on equity and the debt-to-capital ratio.

The mechanisms of the long waves are as follows. Suppose that there is an increase in the expected rate of return on equity. This induces households to invest more in equity, tending to increase equity prices. This has two effects. First, it feeds back to the expected rate of return since there is an increase in capital gains that increases the actual rate of return on equity. This makes households reallocate their wealth towards equity (i.e. the equity-to-deposits ratio increases). Second, the rise in equity prices increases consumption (through the wealth effect) and investment (through Tobin's q), causing higher economic activity and profitability. As a 
result, the profits-to-interest payments ratio goes up, causing a rise in the debt-to-capital ratio. Since loans are equal to deposits in the model, credit expansion increases the wealth of households, further increasing the demand for equities. Overall, the economy experiences a boom where indebtedness and equity prices increase together. However, since there is imperfect asset substitutability, at some point in time the reallocation of wealth towards equities slows down. This sets the stage for the bust phase in which asset prices decline along with the debt-to-capital ratio. It is important to point out that the $3 \mathrm{D}$ system that generates the long waves is generally more unstable when the responsiveness of households' portfolio choice to the expected rate of return on equities is high.

\subsection{Household debt Minsky models}

Household debt was not at the core of Minsky's analysis. However, many heterodox models have been inspired from Minsky in order to analyse household debt and its implications for financial fragility. In these models corporate debt is assumed away. Below we describe first the models that analyse consumer debt and then we turn to the models about mortgages and the housing market.

\subsubsection{Minsky-Veblen models}

In the Minsky-Veblen models (see Kapeller/Schütz 2014; Ryoo/Kim 2014; Kapeller et al. 2016) consumer debt is driven by consumption norms and the inequality between low-income and high-income households. ${ }^{8}$ As inequality increases, the divergence in the consumption of low-income and high-income households increases. Since low-income households are characterised by a Veblenian emulation motive, they take on more debt in order to increase their consumption and 'keep up with the Joneses'. This, however, increases gradually their debt commitments making them more financially fragile. At some point in time, this rise in household financial fragility causes a decline in the expansion of debt, producing a fall in economic activity. Instability is more likely when the emulation motive of low-income households is strong and banks are highly accommodative.

\subsubsection{Real estate price Minsky models}

Ryoo (2016) has recently developed a real estate price Minsky model in which instability and cycles arise through mechanisms that are similar to the mechanisms of his equity price Minsky model presented above. The difference is that household debt is used instead of corporate debt and equity prices are replaced with real estate prices.

How is financial instability caused in this model? Suppose that there is an increase in the expected housing price inflation. This produces an increase in the demand for houses making their price higher. This improves the value of the houses that are used as collateral from households to take on debt. Therefore, banks provide more credit that allows a further appreciation of real estate prices. However, this process comes to an end because the debt commitments of households gradually increase and households become less willing to take on new debt when their indebtedness is already high. Instability is more likely when there is a high sensitivity of the credit supply to the value of the collateral, when housing supply is

\footnotetext{
${ }^{8}$ The first Minsky models with consumer debt were developed by Palley (1994; 1997).
} 
relatively unresponsive to housing prices and when the demand for houses is highly sensitive to the expected capital gains.

\section{Key lessons learned}

Due to the large diversity of the Minsky models, it is not so easy to derive clear lessons from this literature. However, there are some key general lessons that are summarised below.

\section{Lesson 1: Minsky's ideas can be easily incorporated into different heterodox macroeconomic frameworks.}

Minsky was not always clear enough about the stability/instability in the goods market and the dynamics in the labour market. Also, his analysis of the sources of financial fragility was broad and rich and included many different aspects of the financial system. This has given a high flexibility to those who have modelled his ideas. Different researchers have focused on different Minskyan arguments and have incorporated Minsky's ideas into different heterodox macroeconomic frameworks, such as Kaleckian frameworks that assume a stable goods market, Kaldorian frameworks in which the goods market is unstable or Goodwinian frameworks that capture the wage share-capital accumulation interaction. The Minskyan mechanisms introduced in these frameworks produce very rich dynamics that can be combined with some traditional real sector dynamics that can be found in the heterodox literature. Minskyan mechanisms can either be part of the main business cycles or can be viewed as part of longer cycles that co-evolve with the main business cycles.

\section{Lesson 2: There is no single channel through which financial instability can arise.}

In the Kalecki-Minsky, Kaldor-Minsky and Goodwin-Minsky models financial instability arises because firms take on more debt to finance their investment. Higher indebtedness depresses investment through the interest payments channel. This negative effect is reinforced when the interest rate is pro-cyclical. In the credit rationing Minsky models the financial boom and the resulted instability is reinforced by the fact that banks' expectations and profitability improves during periods of high growth, inducing them to expand credit more aggressively. The increase in the leverage of firms goes hand in hand with the rise in the leverage of banks. In the equity price Minsky models equity prices play a key role. The fact that households tend to invest more in the stock market during the boom has expansionary effects and improves the profitability of firms. This facilitates the expansion of debt, increasing financial fragility.

In the household debt models, financial instability arises because of the indebtedness of households. In the Minsky-Veblen models the driver of financial fragility is higher inequality and the emulation motive of low-income households who take on debt to follow the consumption norms determined by high-income households. In the real estate price Minsky models instability arises because of the interaction between the collateral-based lending of banks and the speculation of households in the housing market that produces a housing price bubble.

It is not clear which of these channels is more important in generating financial instability. This largely depends on the period of capitalism that is analysed. For example, the collateralbased housing lending of banks was very important to understand the rise in financial fragility that led to the global financial crisis of 2007-8, but not so important for the financial crises in previous decades. Some of these channels are closer to Minsky's original writings, while other 
channels rely on extensions of his broad ideas about the inherent instability of financial capitalism (see, for example, the household debt Minsky models). Also, there is no consensus on whether asset prices should always be incorporated in a model in order to be considered as a Minskyan one (see the discussion in Ryoo 2013c: 10-11).

However, it is worth pinpointing that all these channels are compatible with each other: the one does not exclude the other. Most Minsky models have focused on one or two of these channels to keep the formal analysis tractable. However, it is possible to examine most of these channels in conjunction using, for example, a stock-flow consistent framework (see e.g. Nikolaidi 2015).

Lesson 3: Instability is more likely when firms, banks or households adopt aggressive investment strategies during the boom. However, these strategies do not necessarily cause higher financial fragility and instability.

In the corporate debt models the economic system can more easily produce instability when firms' investment responds strongly to the rise in profitability and sales, when the supply of credit by banks is highly sensitive to their profitability and economic growth and/or when households tend to speculate a lot when the capital gains on stocks go up. In the household debt models instability is more likely when households desire to buy houses is highly responsive to the appreciation of housing prices and/or when banks are more willing to provide loans to low-income households and engage strongly with collateral-based lending.

However, aggressive investment strategies do not always lead to higher financial fragility and instability. Other parameters and macroeconomic variables in the models also play a key role. For example, as illustrated by the paradox of debt, a high responsiveness of firms' investment to profitability might not increase the leverage of firms if the retention rate is not sufficiently high. Also, in the household debt models instability might not arise if banks are highly willing to provide loans to low-income households but the emulation behaviour of households is not strong enough or if inequality is low.

\section{The way forward}

Although the formal literature on Minsky is large and diversified, there are still many areas that need to be the subject of future research. We will start with some methodological issues and then we will turn to new areas the Minskyan modelling could contribute to.

\subsection{Methodological issues}

\subsubsection{Empirical foundations}

The empirical foundations of most Minsky models are weak. As emphasised in section 2, many models do not conduct any simulation analysis, some models use simulations without making explicit links with real data ${ }^{9}$ and probably only one model (Fazzari et al. 2008) conducts a more careful calibration exercise in which the parameter values are chosen based on real data. This has to change. The new Minsky models have to rely more explicitly on calibration and econometric techniques in order to be more relevant for the real world. It is

\footnotetext{
${ }^{9}$ Note that this is a common weakness of many heterodox macroeconomic models (see Franke 2017).
} 
also necessary to examine more deeply whether Minsky models can quantitatively reproduce the financial cycles observed in the real data (see e.g. Borio 2014).

Moreover, the hypotheses used in the different types of models need to be re-examined based on empirical evidence. For example, the choices that are made about the specification of the investment function, the use of debt or equity as a residual source of finance and the role of asset prices in the consumption function have to be carefully informed from empirical studies. Stronger links between the theoretical models and the empirical literature on Minsky - which largely focuses on the distinction between hedge, speculative and Ponzi units ${ }^{10}-$ should also $^{2}$ be established.

\subsubsection{Agent-based modelling and heterogeneity}

The Minsky models presented in section 2 are all macro models without agent-based structures or heterogeneous financial positions. Arguably, this is not very much in line with Minsky who paid particular attention to the financial fragility at the micro level and emphasised that the financial fragility at the macro level arises when a significant proportion of individual firms are speculative or Ponzi:

'The mixture of hedge, speculative, and Ponzi finance in an economy is a major determinant of its stability. The existence of a large component of positions financed in a speculative or a Ponzi manner is necessary for financial instability' (Minsky 1986 [2008]: 232).

One way to analyse financial fragility in this way is to rely on the recently developed agentbased approach. The advantage of this approach is that the financial fragility at the macro level emerges from the financial fragility of individual firms at the micro level. Actually a few recent studies have followed this direction (e.g. Chiarella/Di Guilmi 2011; Michell 2014; Caiani et al. 2016), developing macro models in which the macro fragility can emerge from the individual behaviour and financial structures of firms. However, a caveat is that agent-based models can become very complicated in practice, making it difficult to identify the underling mechanisms through which financial fragility can arise. An alternative way to take the heterogeneity in financial structures on board is the development of macro models in which the sectors are divided into different sub-sectors with different balance sheet structures (e.g. Dafermos/Papatheodorou 2015; Kapeller et al. 2016).

Future research could draw on these approaches in order to develop Minsky models that pay more emphasis not only to the importance of individual/heterogeneous firms and households but also on the interactions between banks that are characterised by different financial structures.

\subsection{Areas for future research}

\subsubsection{Open economies}

Open economy issues are broadly missing in Minsky models. One exception is Foley (2003) who has developed a model in which capital inflows play an important role in the dynamics of financial fragility. However, his model abstracts from the role of exchange rates and the importance of balance sheet structures. A more integrated open economy Minsky model

\footnotetext{
10 See e.g. Schroeder (2009), Mulligan (2013), Nishi (2016) and Davis et al. (2017).
} 
should pay explicit attention to the interaction between exchange rates, interest rates and foreign currency-denominated liabilities that has been the subject of various Minsky-inspired studies (see e.g. Kregel 1998; De Paula/Alves 2000; Arestis/Glickman 2002; Kaltenbrunner 2015). The recent model of Köhler (2016) could be a useful starting point in this direction.

There is also an absence of Minsky models that investigate how financial fragility is affected by the industrial structure of an economy which is a key factor that affects imports and exports. It is generally expected that credit expansion is more likely to increase the financial fragility of domestic households and firms when the industrial structure of the economy is weak rather than when it is strong. A weak net export performance implies that new credit is less likely to increase domestic output and thus the domestic incomes that are used to repay debt; it is hence more conducive to financial fragility.

\subsubsection{Shadow banking}

Since the 1970s and the 1980s when Minsky developed his FIH, the global financial system has been transformed significantly. New financial products and financial institutions have been created, giving rise to the so-called 'shadow banking' system. This evolution of the financial system is broadly in line with Minsky's analysis about the financial fragility that stems from the 'money manager capitalism'. Indeed, Minsky himself had expressed his concerns about the impact of securitisation - a key process within the shadow banking system- on the lending practices of banks:

'Securitization implies that there is no limit to bank initiative in creating credits for there is no recourse to bank capital...' (Minsky 1987: 3; emphasis in original).

An interesting avenue for further research is therefore the development of credit rationing Minsky models about the shadow-banking related financial fragility, focusing, for example, on the interaction between the price of complex financial instruments (such as Mortgage-Backed Securities (MBSs)), the provision of loans and the leverage of shadow banks. Nikolaidi (2015) has recently developed a stock-flow consistent model that pays special attention to some of these issues. The model shows that when banks increase their engagement with securitisation activities, the higher availability of loans can lead to a credit and asset price boom that ultimately results in a higher rate of loan default with adverse effects on macroeconomic performance.

\subsubsection{Environmental issues}

Can Minsky be used for the analysis of the financial implications of climate change and other environmental problems? In one of his recent speeches, Mark Carney talked about the possibility of experiencing a climate Minsky moment, which broadly refers to the financial instability that could result from climate change or from actions taken to tackle climate change (Carney 2016).

One can think of at least three ways via which a climate Minsky moment can arise. The first refers to a pessimistic scenario in which no radical measures are taken in the next decades to increase the use of renewables and reduce the energy intensity of global production and consumption. Under this scenario, the catastrophes caused by global warming (e.g. typhoon, hurricanes) could lead to capital destruction and lower economic growth that would harm firms' profitability and hence their ability to repay loans. They could also result in financial 
behaviour that might lead to asset price deflation. Dafermos et al. (2016) have recently developed an ecological macroeconomic model that analyses these channels.

A climate Minsky moment could also arise under a more optimistic scenario in which governments commit themselves to reduce carbon emissions rapidly in order to avoid a $2^{\circ} \mathrm{C}$ global warming. It might then be the case that investors will realise that the fossil fuel companies will not be very profitable in the future. This could lead them to sell stocks and bonds of these companies, causing asset price deflation. Some fossil-fuel companies might also default, causing financial instability due to their interrelationships with the rest of the financial system (see e.g. Carbon Tracker Initiative 2011; Battiston et al. 2017).

There is also a third scenario under which a Minsky climate moment can take place. Suppose that the transition to a low-carbon economy does not initially cause any significant financial problems. However, green finance becomes dominant and green projects prove very successful, generating a euphoria about the green economy. This could create a kind of a green credit boom that would resemble the standard process through which financial fragility increases as in Minsky's FIH. Note that compared to the two scenarios mentioned above, in the case of green boom a climate Minsky moment arises as a result of an endogenous process and not because of some environmental shocks imposed outside the financial system. The formalisation of a green Minsky boom would be an interesting modelling exercise.

\section{Conclusion}

Modelling Minsky is not a straightforward task. Minsky's writings are very rich and there is no single way to formalise his ideas. Thus, it comes as no surprise that Minsky models differ so much. As shown in this paper, these differences primarily pertain to the source of financial instability, the type of heterodox framework into which Minskyan ideas are incorporated and the purpose and the nature of the dynamic analysis. The paper has presented a classification of the key Minsky models and has analysed their main similarities and differences.

The paper has also outlined the main lessons learned from the literature on Minsky modelling. A first lesson is that Minsky's ideas can be easily incorporated into different heterodox macroeconomic frameworks. A second lesson is that there is no single channel through which financial instability can arise. And a third lesson is that instability is more likely when firms, banks or households adopt aggressive investment strategies during the boom. However, these strategies do not necessarily cause higher financial fragility and instability.

Where should the research on Minskyan modelling focus on in the next decade or so? The paper has called for more empirically-driven models that rely on calibration or econometric techniques, has pointed out the usefulness of agent-based approaches and has highlighted the need for the development of Minsky models on open economy, shadow banking and environmental issues. This research on Minskyan modelling should be part of a broader research agenda that would put the key role of the financial system at the core of macroeconomic modelling, departing from the financial 'frictions' approach of the dominant macroeconomic paradigm. 


\section{References}

Arestis, P., Glickman, M. (2002): Financial crisis in Southeast Asia: dispelling illusion the Minskyan way, in: Cambridge Journal of Economics, 26(2), 237-260.

Argitis, G., Nikolaidi, M. (2014): The financial fragility and the crisis of the Greek government sector, in: International Review of Applied Economics, 28(3), 274-292.

Asada, T. (2001): Nonlinear dynamics of debt and capital: a Post-Keynesian analysis, in: Aruka, Y. (ed.), Evolutionary Controversies in Economics, Tokyo: Springer-Verlag.

Battiston, S., Mandel, A., Monasterolo, I., Schütze, F., Visentin, G. (2017): A climate stresstest of the financial system, in: Nature Climate Change, 7, 283-288.

Bhattacharya, S., Goodhart, C.A.E., Tsomocos, D.P., Vardoulakis, A.P. (2015): A reconsideration of Minsky's financial instability hypothesis, in: Journal of Money, Credit and Banking, 47(5), 931-973.

Borio, C. (2014): The financial cycle and macroeconomics: what have we learnt?, in: Journal of Banking and Finance, 45, 182-198.

Caiani, A., Godin, A., Caverzasi, E., Gallegati, M., Kinsella, S., Stiglitz, J.E. (2016): Agent based-stock flow consistent macroeconomics: towards a benchmark model, in: Journal of Economic Dynamics and Control, 69, 375-408.

Carbon Tracker Initiative (2011): Unburnable carbon: are the world's financial markets carrying a carbon bubble?, URL: http://www.carbontracker.org/report/carbon-bubble/.

Carney, M. (2016): Resolving the climate paradox, Speech Arthur Burns Memorial Lecture, Berlin 22 September 2016, URL: http://www.fsb.org/wp-content/uploads/Resolving-theclimate-paradox.pdf.

Charles, S. (2008): Teaching Minsky's financial instability hypothesis: a manageable suggestion, in: Journal of Post Keynesian Economics, 31(1), 125-138.

Charles, S. (2016): Is Minsky's financial instability hypothesis valid?, in: Cambridge Journal of Economics, 40(2), 427-436.

Chiarella, C., Di Guilmi, C. (2011): The financial instability hypothesis: a stochastic microfoundation framework, in: Journal of Economic Dynamics and Control, 35(8), 1151-1171.

Dafermos, Y. (2017): Debt cycles, instability and fiscal rules: a Godley-Minsky model, in: Cambridge Journal of Economics, forthcoming.

Dafermos, Y., Papatheodorou, C. (2015): Linking functional with personal income distribution: a stock-flow consistent approach, in: International Review of Applied Economics, 29(6), 787-815.

Dafermos, Y., Nikolaidi, M., Galanis, G. (2016): Climate change, financial stability and monetary policy, Paper presented at the Bank of England Conference 'Central Banking, Climate Change and Environmental Sustainability', 14-15 November, URL: http://www.bankofengland.co.uk/research/Documents/conferences/ccfsandmpspk.pdf.

Davis, L.E., de Souza J.P.A., Hernandez, G. (2017): An empirical analysis of Minsky regimes in the US economy, in: Working Paper No 08, UMass Amherst.

Delli Gatti, D., Gallegati, M. (1990): Financial instability, income distribution, and the stock market, in: Journal of Post Keynesian Economics, 12(3), 356-374.

Delli Gatti, D., Gallegati, M., Gardini, L. (1994): Complex dynamics in a simple macroeconomic model with financing constraints, in: Dymski, G., Pollin, R. (eds), New Perspectives in Monetary Macroeconomics, USA: University of Michigan.

De Paula, L.F.R., Alves, A.J. (2000): External financial fragility and the 1998-1999 Brazilian currency crisis, in: Journal of Post Keynesian Economics, 22(4), 589-617.

Dutt, A.K. (1995): Internal finance and monopoly power in capitalist economies: a reformulation of Steindl's growth model, in: Metroeconomica, 46(1), 16-34.

Eggertsson, G., Krugman, P. (2012): Debt deleveraging, and the liquidity trap: a FisherMinsky-Koo approach, in: The Quarterly Journal of Economics, 127(3), 1469-1513. 
Farmer, R. (2013): Animal spirits, financial crises and persistent unemployment, in: Economic Journal, 123(568), 317-340.

Fazzari, S., Ferri, P., Greenberg, E. (2008): Cash flow, investment, and Keynes-Minsky cycles, in: Journal of Economic Behavior and Organization, 65 (3-4), 555-572.

Ferrari-Filho, F., Terra, F.H.B., Conceição, O.A.C. (2010): The financial fragility hypothesis applied to the public sector: an analysis for Brazil's economy from 2000 to 2008, in: Journal of Post Keynesian Economics, 33(1): 151-168.

Foley, D. (1987): Liquidity-profit rate cycles in a capitalist economy, in: Journal of Economic Behavior and Organization, 8(3), 363-376.

Foley, D. (2003): Financial fragility in developing economies, in: Dutt, A., Ros, J. (eds), Development Economics and Structuralist Macroeconomics, UK and USA: Edward Elgar.

Franke, R. (2017): What output-capital ratio to adopt for macroeconomic calibrations?, in: International Review of Applied Economics, 31(2), 208-224

Franke, R., Semmler, W. (1989): Debt financing of firms, stability, and cycles in a dynamical macroeconomic growth cycle, in: Semmler, W. (ed.), Financial Dynamics and Business Cycles, New York and London: M.E Sharpe.

Grasselli, M.R., Costa Lima, B. (2012): An analysis of the Keen model for credit expansion, asset price bubbles and financial fragility, in: Mathematical Financial Economics, 6(3), 191-210.

Hein, E. (2007): Interest rate, debt, distribution and capital accumulation in a post-Kaleckian model, in: Metroeconomica, 58(2), 310-339.

Isaac, A.G., Kim, Y.K. (2013): Consumer and corporate debt: a Neo- Kaleckian synthesis, in: Metroeconomica, 64(2), 244-271.

Jarsulic, M. (1989): Endogenous credit and endogenous business cycles, in: Journal of Post Keynesian Economics, 12(1), 35-48.

Kaltenbrunner, A. (2015): A post Keynesian framework of exchange rate determination: a Minskyan approach, in: Journal of Post Keynesian Economics, 38(3), 426-448.

Kapeller, J., Schütz, B. (2014): Conspicuous consumption, inequality and debt: the nature of consumption-driven profit- led regimes, in: Metroeconomica, 66(1), 51-70.

Kapeller, J., Landesmann, M., Mohr, F. X., Schütz, B. (2016): Government policies and financial crises: mitigation, postponement or prevention?, in: Working Paper No 126, The Vienna Institute for International Economic Studies, wiiw.

Köhler, K. (2016): Currency devaluations, aggregate demand, and debt dynamics in an economy with foreign currency liabilities, in: Working Paper No 78/2016, Institute for International Political Economy Berlin.

Keen, S. (1995): Finance and economic breakdown modelling Minsky's 'financial instability hypothesis', in: Journal of Post Keynesian Economics, 17, 607-635.

Keen, S. (2013): A monetary Minsky model of the Great Moderation and the Great Recession, in: Journal of Economic Behavior and Organization, 86, 221-235.

Kregel, J. (1998): Yes, 'it' did happen again, in: Working Paper No 234, The Levy Economics Institute.

Kregel, J. (2008): Minsky's cushions of safety: systemic risk and the crisis in the U.S. subprime mortgage crisis, in: Public Policy Brief No 93, The Levy Economics Institute.

Lavoie, M. (1995): Interest rates in Post-Keynesian models of growth and distribution, in: Metroeconomica, 46(2), 146-177.

Lavoie, M., Seccareccia, M. (2001): Minsky's financial fragility hypothesis: a missing macroeconomic link?, in: Ferri, P., Bellofiore, R. (eds), Financial Fragility and Investment in the Capitalist Economy: The Economic Legacy of Hyman Minsky, Vol 2, Cheltenham: Edward Elgar.

Lima G., Meirelles A. (2007): Macrodynamics of debt regimes, financial instability and growth, in: Cambridge Journal of Economics, 31(4), 563-580. 
Michell, J. (2014): A Steindlian account of the distribution of corporate profits and leverage: a stock-flow consistent macroeconomic model with agent-based microfoundations, Working Paper No 1412, Post-Keynesian Economics Study Group (PKSG).

Minsky, H.P. (1975): John Maynard Keynes, New York: Columbia University Press.

Minsky, H.P. (1982): Inflation, Recession and Economic Policy, New York: M.E. Sharpe.

Minsky, H.P. (1987): Securitization, Handout Econ 335A, Fall, mimeo, in Levy archives, published as Policy Note No 2, The Levy Economics Institute.

Minsky, H.P. (2008): Stabilizing an Unstable Economy, New Haven: Yale University Press.

Mulligan, R. (2013): A sectoral analysis of the financial instability hypothesis, in: The Quarterly Review of Economics and Finance, 53(4), 450-459.

Nikolaidi, M. (2014): Margins of safety and instability in a macrodynamic model with Minskyan insights, in: Structural Change and Economic Dynamics, 31, 1-16.

Nikolaidi, M. (2015): Securitisation, wage stagnation and financial fragility: a stock-flow consistent perspective, in: Greenwich Papers in Political Economy No 27.

Nikolaidi, M., Stockhammer, E. (2017): Minsky models: a structured survey, in: Working Paper No 1706, Post-Keynesian Economics Study Group (PKSG).

Nishi, H. (2012). A dynamic analysis of debt- led and debt- burdened growth regimes with Minskian financial structure, in: Metroeconomica, 63(4), 634-660.

Nishi, H. (2016): An empirical contribution to Minsky's financial fragility: evidence from nonfinancial sectors in Japan, in: Kyoto University, Graduate School of Economics Discussion Paper Series No E-16-007.

Palley, T.I (1994): Debt, aggregate demand, and the business cycle: an analysis in the spirit of Kaldor and Minsky, in: Journal of Post Keynesian Economics, 16(3), 371-390.

Palley, T.I. (1997): Endogenous money and the business cycle, in: Journal of Economics, 65(2), 133-149.

Ryoo, S. (2010): Long waves and short cycles in a model of endogenous financial fragility, in: Journal of Economic Behaviour and Organization, 74(3), 163-186.

Ryoo, S. (2013a): Minsky cycles in Keynesian models of growth and distribution, in: Review of Keynesian Economics, 1(1), 37-60.

Ryoo, S. (2013b): Bank profitability, leverage and financial instability: a Minsky-Harrod model, in: Cambridge Journal of Economics, 37(5), 1127-1160.

Ryoo, S. (2013c): The paradox of debt and Minsky's financial instability hypothesis, in: Metroeconomica, 64(1), 1-24.

Ryoo, S. (2016): Household debt and housing bubble: a Minskian approach to boom-bust cycles, in: Journal of Evolutionary Economics, 26, 971-1006.

Ryoo, S., Kim, Y.K. (2014): Income distribution, consumer debt and keeping up with the Joneses, in: Metroeconomica, 65(4), 585-618.

Sasaki, H., Fujita, S. (2012): Increased shareholder power and its long-run macroeconomic effects in a Kaleckian model with debt accumulation, in: The Kyoto Economic Review, 81(2), 82-105.

Schroeder, S. (2009): Defining and detecting financial fragility: New Zealand's experience, in: International Journal of Social Economics, 36(3), 287-307.

Semmler, W. (1987): A macroeconomic limit cycle with financial perturbations, in: Journal of Economic Behavior and Organisation, 8(3), 469-495.

Setterfield, M. (2004): Financial fragility, effective demand and the business cycle, in: Review of Political Economy, 16(2), 207-223.

Skott, P. (1989): Conflict and Effective Demand in Economic Growth, Cambridge: Cambridge University Press.

Skott, P. (1994): On the modeling of systemic financial fragility, in: Dutt, A. (ed.), New Directions in Analytical Political Economy, Aldershot: Edward Elgar. 
Sordi, S., Vercelli, A. (2014): Unemployment, income distribution and debt-financed investment in a growth cycle model, in: Journal of Economic Dynamics and Control, 48, 325-348.

Stockhammer, E., Michell, J. (2017): Pseudo-Goodwin cycles in a Minsky Model, in: Cambridge Journal of Economics, 41(1), 105-125.

Taylor, L., O'Connell, S.A. (1985): A Minsky crisis, in: Quarterly Journal of Economics, 100 (Supplement), 871-885.

Vercelli, A. (2011): A perspective on Minsky moments: revisiting the core of the financial instability hypothesis, in: Review of Political Economy, 23(1), 49-67.

Wray, R. (2009): The rise and fall of money manager capitalism: a Minskian approach, in: Cambridge Journal of Economics, 33(4), 807-828. 